\title{
Changes in Serum Cytokine Concentration : A Morphological Study of Liver Cirrhosis Induced by Common Bile Duct Ligation in Rats
}

\author{
Byung Seok Lee, M.D., Nam Jae Kim, M.D., Hyun Yong Jeong, M.D., \\ Heon Young Lee, M.D., Dae Young Kang, M.D.* and Seung Moo Noh, M.D. ${ }^{+}$ \\ Departments of Internal Medicine, Pathology* and General Surgery ${ }^{+}$, \\ Chungnam National University College of Medicine, Daejeon, Korea
}

\begin{abstract}
Background: Liver cirrhosis is a diffuse hepatic fibrosis and nodule formation. The transforming growth factor- $\beta 1$ (TGF- $\beta$ 1) and interleukin-10 (IL-10) are very important cytokines in hepatic fibrogenesis. The aim of this study was to examine the relationship between the changes of the serum cytokines and morphological changes following common bile duct ligation in experimental rats.

Methods: Common bile ducts of fifty male Sprague-Dawley rats were ligated and seven male rats were set aside as controls. Five rats each were sacrificed in 1, 2, 4, 6, 8, and 10 experimental weeks. Light microscopic studies and liver function tests were performed during the above experimental weeks. The levels of serum TGF- $\beta 1$ and $\mathrm{IL}-10$ were analyzed by ELISA. Also, alpha smooth muscle actin (a-SMA) immunohistochemical stains were performed.

Results: On the eighth week after common bile duct ligation, most hepatic lobular areas had been replaced by proliferated bile ducts and fibrous tissue (typical biliary cirrhosis). Serum TGF- $\beta 1$ levels between the control group and the common bile duct ligation group showed statistically significant changes. The a-SMA was stained at proliferated bile ducts. These findings were correlated with each other.

Conclusion: Thus, this experiment may clarify our understanding of the mechanism in liver fibrogenesis. Also, indicated is a need to explore the therapeutic potential of these cytokines as anti-fibrotic agents.
\end{abstract}

Key Words: TGF- $\beta 1$, Interleukin-10, Alpha-SMA, Cytokine, Liver cirrhosis

\section{INTRODUCTION}

Liver cirrhosis is a chronic liver disease caused by viruses, alcohol, various drugs and congenital disease. Complications of this disease include gastrointestinal bleeding, ascites, hepatic failure and hepatocellular carcinoma. However, there is no definite treatment of this disease. Until 1980, in Korea, hepatitis B was a prominent cause of liver cirrhosis, but frequency was decreased due to life-style changes and vaccination, especially for the young ${ }^{1)}$. However, alcoholic cirrhosis has increased ${ }^{2}$. Hepatocellular carcinoma associated with liver cirrhosis is an important cause of death in $\mathrm{Korea}^{3)}$.
Therefore, an understanding of the pathogenesis of liver cirrhosis and fibrosis is an important task in the fight against hepatocellular carcinoma.

Liver fibrosis causes scar formation regardless of the various causes and this process is similar in the other organs. Fibrosis of the liver is increased in the extracellular matrix and results in loss of liver parenchymal cells. Various factors, such as cell and extracellular matrix and cytokines, are known in the process of hepatic fibrosis. Hepatic stellate cells (Ito cell or lipocyte) are important cells that secrete the extracellular matrix. These cells are in a resting state normally, but are activated when the cytokines or oxidative stress are given.

- Received : September 24, 2002.

- Accepted : November 4, 2002.

- Correspondence to : Byung Seok Lee, M.D., Chung Nam National University Hospital, Daesa-dong, Jung-gu, Daejeon 301-721, Korea. E-mail : gie001@cnuh.co.kr 
Activated hepatic stellate cells increase the secretion and accumulation of extracellalar matrix surrounding the space of Disse $^{4,5)}$.

Cytokines which activate hepatic stellate cells are a transforming growth factor -beta 1 (TGF- $\beta 1$ ), platelet-derived growth factor (PDGF), fibroblast growth factor (FGF) and endothelin-1 (ET-1). TGF- $\beta 1$ is a key cytokine that initiates and terminates tissue repair and development of hepatic fibrosis $^{6}$. In fact, TGF- $\beta 1$ is the most potent mediator in fibrogenic mechanism. TGF- $\beta 1$ plays an important role in the production of extracellular matrix deposition and prevention of the degradation of extracellular proteins by enhancing production of fibronectin and collagen in the liver. Excessive or sustained production of TGF- $\beta 1$ is an important mediator of liver fibrosis ${ }^{7,8)}$.

Interleukin-10 is a potent anti-inflammatory and anti-fibrotic cytokine. This cytokine increases in the early stage of hepatic stellate cell activation and the abscence of this leads to enhanced fibrogenesis ${ }^{9,}$ 10).

In this report, we demonstrate the relationship between the morphological changes and serum cytokines in liver cirrhosis induced by common bile duct ligation in rats.

\section{MATERIALS AND METHODS}

\section{Experimental animals}

Four-week old male Sprague -Dawley rats, about $200 \mathrm{~g}$, were used (kindly supplied by Biogenomics Co, Charles River Technology License). The experimental group (cholestatic liver injury group by common bile duct ligation) totalled fifty rats and the control group was seven rats. All animals received humane care in compliance with the Guide for the "Care and Use of Laboratory Animals" prepared by the Natural Institute of Health (NIH Publication No. 85-23, revised 1996).

\section{Chemicals and serologic tests}

Cholestatic liver injury was induced in male rats by ligation and transection of the common bile duct. These animals were sacrificed during 12 weeks. Five rats were sacrificed every two weeks. Blood samples were obtained from cardiac punctures under ketamin with xylazine (Rumpun, Seoul, Korea) anesthesia, and centrifuged at $10,000 \mathrm{~g}$ for 5 minutes after 1, 2, 4, 6, 7, 8, 10 experimental week. Serum was stored at $-70^{\circ} \mathrm{C}$. Liver function tests were performed on each experimental week (total protein, albumin, aspartate aminotransferase, alanine aminotransferase, alkaline phosphatase, gamma glutamyl transpeptidase); and serum transforming growth factor- $\beta 1$ (TGF- $\beta 1$ ) and interleukin-10 (IL-10) concentration were analyzed using the enzyme-linked immunosorbent assay kit (Quantikine, R\&D System).

Assay procedures of TGF- $\beta 1$ were as follows. Prepare all reagents, working standards and activated samples as instructed. Add $200 \mu \mathrm{L}$ standard or activated sample to each well and incubate for 3 hours. Aspirate and wash 3 times. Add $200 \mu \mathrm{L}$ conjugate to each well and incubate for 1.5 hours. Aspirate and wash 3 times. Add $200 \mu \mathrm{L}$ substrate solution to each well and incubate for 20 minutes. Add $50 \mu \mathrm{L}$ stop solution to each well and read at $450 \mathrm{~nm}$ within 30 minutes. Serum $\mathrm{IL}-10$ concentration assay was as follows. Add $50 \mu \mathrm{L}$ assay diluting agent to the center of each well. Add $50 \mu \mathrm{L}$ standard, control, or sample to the center of each well, and incubate for 2 hours. Aspirate and wash each well 5 times. Add $100 \mu \mathrm{L}$ conjugate to each well and incubate for 2 hours. Aspirate and wash each well 5 times. Add $100 \mu \mathrm{L}$ substrate solution to each well and incubate for 30 minutes. Add $100 \mu \mathrm{L}$ stop solution to each well and read optical density at $450 \mathrm{~nm}$.

\section{Microscopic and immunohistochemical staining}

Liver specimens of experimental rats were obtained and routinely fixed in 10\% formalin and embedded in paraffin blocks. Using thin tissue section, hematoxylin-eosin (HE) and Masson trichrome stains were performed. Alpha smooth muscle actin has been widely used to detect stellate cell activation. Incubate with monoclonal antibodies for alpha smooth muscle actin (anti-SMA) (Nichirei Co., Tokyo, Japan). After rinsing, tissues were incubated with a biotinylated rabbit antimouse IgG $F\left(a b^{\prime}\right)$ fragment (DAKO Japan, Kyoto, Japan). Thereafter, sections were incubated in the avidin biotin complex (ABC) solution (Vectastatin, Burlingame, CA, USA) $)^{11)}$.

\section{Statisical analysis}

The results were presented as mean \pm standard deviations. Statistical correlations were checked by the unpaired $T$ test and Chi-square test using SPSS 10 for the Windows program.

\section{RESULTS}

Death rate of experimental rats

A total of 11 rats died during the experimental periods. The cause of death was peritonitis in the common bile duct ligation group. There were no deaths in the control group.

\section{Morphological change of experimental rats}

Ascites appeared after the fourth week in the common bile duct ligation group and body weight increased. Cysts of bile duct were prominent and some cysts ruptured (Table 1, Figure 1). 
Table 1. Characteristics of Experimental Rats (Mean $\pm S D$ )

\begin{tabular}{ccccc}
\hline \hline Week & Group & Body wt. & Liver \& cyst wt. & $\begin{array}{c}\text { Net liver wt. } \\
\text { (liver wt.-cyst wt.) }\end{array}$ \\
\hline 1W & I & 390.0 & 12.9 & \\
& II & $271.7 \pm 22.5$ & $14.0 \pm 2.9$ & \\
2W & I & 390.0 & 15.4 & \\
& II & $297.5 \pm 36.9$ & $23.9 \pm 6.7$ & \\
4W & I & 370.0 & 15.9 & \\
& II & $327.5 \pm 55.6$ & $33.3 \pm 6.7$ & \\
$6 \mathrm{~W}$ & I & 500.0 & 18.4 & \\
& II & $360.0 \pm 41.1$ & $42.4 \pm 12.4$ & $27.2 \pm 7.7$ \\
$8 \mathrm{~W}$ & I & 450.0 & 15.5 & \\
& II & $426.0 \pm 55.5$ & $34.0 \pm 3.7$ & $28.7 \pm 1.9$ \\
$10 \mathrm{~W}$ & I & 470.0 & 17.1 & \\
& II & $454.0 \pm 60.2$ & $37.4 \pm 8.8$ & $28.2 \pm 9.1$ \\
\hline
\end{tabular}

I, Control group; II, Common bile duct ligation group; Wt., Weight (gram)

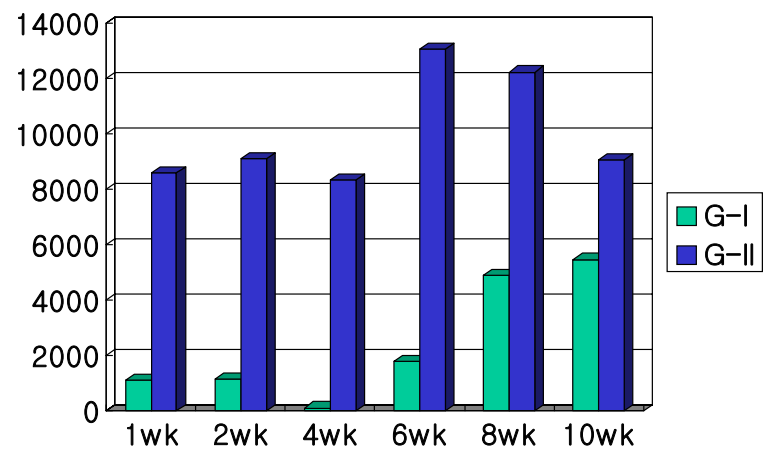

Figure 1. Change of serum TGF- $\beta 1$ concentrations. The serum TGF- $\beta 1$ levels in the control (G-I) and common bile duct ligation group (G-II) show statistically significant changes.
Changes of chemistry

Between the control group and the common bile duct ligated group, statistically significant changes of the serum liver enzymes were found in albumin, AST, ALT and alkaline phosphatase (Table 2).

\section{Changes of cytokines}

Serum TGF- $\beta 1$ levels between the control group and the common bile duct ligation group showed statistically significant changes $(p<0.05)$. The serum TGF- $\beta 1$ levels revealed high values from the sixth experimental week to the eighth experimental week. The serum IL-10 levels of the control and bile duct ligation group did not show statistically significant changes (Table 3).

Table 3. Changes of Serum Cytokine Values (Mean \pm SD)

\begin{tabular}{cccc}
\hline \hline Week & Group & TGF- $\beta 1(\mathrm{pg} / \mathrm{mL})$ & IL-10 $(\mathrm{pg} / \mathrm{mL})$ \\
\hline \multirow{2}{*}{$1 \mathrm{~W}$} & I & 1115.5 & 6.1 \\
& II & $8594.6 \pm 4898.3$ & $18.1 \pm 21.5$ \\
$2 \mathrm{~W}$ & I & 1160.9 & 11.9 \\
& II & $9115.3 \pm 8688.5$ & $26.2 \pm 34.2$ \\
$4 \mathrm{~W}$ & I & 1057.0 & 0.0 \\
& II & $8337.6 \pm 3727.9$ & $2.7 \pm 2.7$ \\
$6 \mathrm{~W}$ & I & 1795.7 & 3.7 \\
& II & $13055.5 \pm 6339.3$ & $0.7 \pm 1.7$ \\
$8 \mathrm{~W}$ & I & 4898.8 & 0.0 \\
& II & $12229.7 \pm 8914.8$ & $0.4 \pm 1.1$ \\
$10 \mathrm{~W}$ & I & 5469.0 & 0.0 \\
& II & $9069.7 \pm 5450.3$ & $1.3 \pm 3.1$ \\
\hline
\end{tabular}

I, Control group; II, Common bile duct ligation group; IL-10, Interleukin-10; TGF- $\beta 1$, Transforming growth factor $\beta 1$.

Table 2. The Changes of Serum Enzyme Values

\begin{tabular}{|c|c|c|c|c|c|c|c|c|}
\hline Week & Group & $\begin{array}{l}\text { T.P } \\
(\mathrm{g} / \mathrm{L})\end{array}$ & $\begin{array}{l}\text { Alb } \\
\text { (g/L) }\end{array}$ & $\begin{array}{l}\text { AST } \\
(\mathrm{IU} / \mathrm{L})\end{array}$ & $\begin{array}{c}\mathrm{ALT} \\
(\mathrm{IU} / \mathrm{L})\end{array}$ & $\begin{array}{c}\text { TB } \\
(\mathrm{mg} / \mathrm{L})\end{array}$ & $\begin{array}{l}\text { ALP } \\
(\mathrm{IU} / \mathrm{L})\end{array}$ & $\begin{array}{l}\text { GGT } \\
(\mathrm{IU} / \mathrm{L})\end{array}$ \\
\hline $1 \mathrm{~W}$ & $\begin{array}{l}\text { I } \\
\text { II }\end{array}$ & $\begin{array}{c}5.8 \\
5.6 \pm 0.8\end{array}$ & $\begin{array}{c}3.5 \\
3.2 \pm 0.6\end{array}$ & $\begin{array}{c}121.0 \\
452.0 \pm 151.6\end{array}$ & $\begin{array}{c}34.0 \\
129.3 \pm 68.9\end{array}$ & $\begin{array}{c}0.3 \\
5.7 \pm 4.7\end{array}$ & $\begin{array}{c}356.0 \\
376.0 \pm 74.3\end{array}$ & $\begin{array}{c}1.0 \\
4.6 \pm 2.1\end{array}$ \\
\hline $2 W$ & $\begin{array}{l}\text { I } \\
\text { II }\end{array}$ & $\begin{array}{c}5.8 \\
6.5 \pm 0.3\end{array}$ & $\begin{array}{c}3.7 \\
3.6 \pm 0.2\end{array}$ & $\begin{array}{c}123 \\
870.0 \pm 234.5\end{array}$ & $\begin{array}{c}34.0 \\
167.5 \pm 63.6\end{array}$ & $\begin{array}{c}0.2 \\
7.7 \pm 5.2\end{array}$ & $\begin{array}{c}293.0 \\
433.0 \pm 111.4\end{array}$ & $\begin{array}{c}1.0 \\
15.3 \pm 12.0\end{array}$ \\
\hline $4 W$ & I & $\begin{array}{c}5.5 \\
6.6 \pm 0.9\end{array}$ & $\begin{array}{c}3.4 \\
2.9 \pm 0.8\end{array}$ & $\begin{array}{c}81.0 \\
572.0 \pm 223.2\end{array}$ & $\begin{array}{c}33.0 \\
111.8 \pm 58.6\end{array}$ & $\begin{array}{c}0.3 \\
8.2 \pm 1.6\end{array}$ & $\begin{array}{c}169.0 \\
428.3 \pm 57.1\end{array}$ & $\begin{array}{c}0.0 \\
18.0 \pm 4.9\end{array}$ \\
\hline $6 \mathrm{~W}$ & $\begin{array}{l}\text { I } \\
\text { II }\end{array}$ & $\begin{array}{c}6.2 \\
6.4 \pm 1.3\end{array}$ & $\begin{array}{c}3.6 \\
2.3 \pm 0.4\end{array}$ & $\begin{array}{c}72.0 \\
827.3 \pm 305.8\end{array}$ & $\begin{array}{c}37.0 \\
156.9 \pm 59.5\end{array}$ & $\begin{array}{c}0.2 \\
8.7 \pm 1.6\end{array}$ & $\begin{array}{c}72 \\
417.9 \pm 98.7\end{array}$ & $\begin{array}{c}1.0 \\
28.8 \pm 23.3\end{array}$ \\
\hline $8 W$ & $\begin{array}{l}\text { I } \\
\text { II }\end{array}$ & $\begin{array}{c}5.9 \\
5.9 \pm 1.1\end{array}$ & $\begin{array}{c}3.3 \\
2.2 \pm 0.4\end{array}$ & $\begin{array}{c}91.0 \\
417.2 \pm 182.8\end{array}$ & $\begin{array}{c}25.0 \\
109.6 \pm 36.0\end{array}$ & $\begin{array}{c}0.3 \\
4.5 \pm 1.1\end{array}$ & $\begin{array}{c}118.0 \\
265.8 \pm 76.4\end{array}$ & $\begin{array}{c}1.0 \\
18.4 \pm 6.9\end{array}$ \\
\hline $10 \mathrm{~W}$ & I & $\begin{array}{c}5.8 \\
7.0 \pm 1.2\end{array}$ & $\begin{array}{c}3.5 \\
2.5 \pm 0.6\end{array}$ & $\begin{array}{c}77.0 \\
440.8 \pm 94.8\end{array}$ & $\begin{array}{c}40.0 \\
95.6 \pm 21.7\end{array}$ & $\begin{array}{c}0.1 \\
4.4 \pm 1.6\end{array}$ & $\begin{array}{c}112.0 \\
343.8 \pm 84.6\end{array}$ & $\begin{array}{c}1.0 \\
34.8 \pm 55.5\end{array}$ \\
\hline
\end{tabular}

I, Control group; II, Common bile duct ligation group; AST, aspartate aminotransferase; ALT, alanine aminotransferase; ALP, alkaline phosphatase; TB, total bilirubin; GGT, gamma glutamyl transpeptidase 


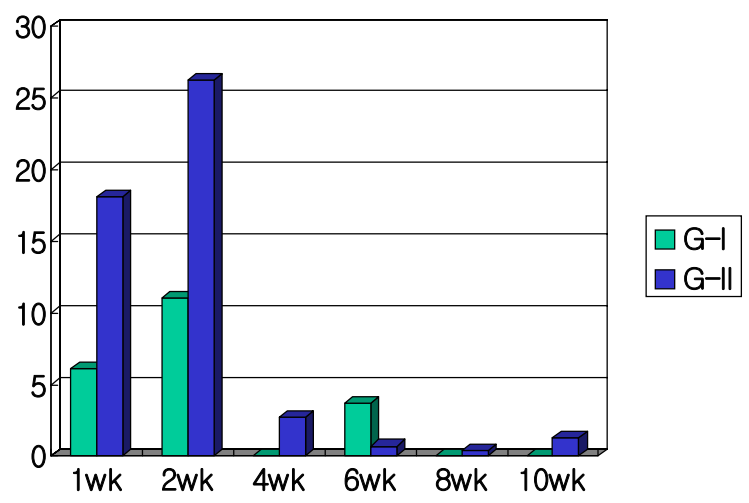

Figure 2. Change of serum interleukin-10 concentration. The serum interleukin levels in the control (G-I) and common bile duct ligation group (G-II) at early experimental weeks show statistically significant changes.

\section{Liver biopsies from rats}

The morphological changes of the common bile duct ligation group include bile duct proliferation and dilatation and inflamatory cell infiltration. By the eighth week after common bile duct ligation, most hepatic lobular areas were replaced by proliferated bile ducts and fibrous tissue (typical biliary cirrhosis). With respect to immunohistochemical stains, most hepatic lobular areas are replaced by proliferative bile ducts and a-SMA were stained after eighth experimental week. These findings are correlated with each other.

\section{DISCUSSION}

Liver cirrhosis is defined as the end stage liver disease and as an irreversible state characterized by regenerating nodule formation and diffuse fibrotic change ${ }^{12,13)}$. The causes of cirrhosis are varied and include viral infection, alcohol and chemical agents and birth metabolism error, but the end results are the same. The complications of cirrhosis are ascites, variceal bleeding, hepatic encephalopathy and hepatocellular carcinoma. It is essential to understand the hepatic fibrosis in liver cirrhosis. Hepatic stellate cells (previous called Ito cell, fat-storing or perisinusoidal cells) are fat-storing perisinusoidal cells and are importamt cells in hepatic fibrosis. Hepatic stellate cells are activated during liver cell injury, including acute and chronic liver disease and then white blood-cell chemoattractant releases the various cytokines and oxygenfree radicals. Also, activated stellate cells supply the type I collagen and extracellular matrix and these materials were accumulated in the space of Disse. These processes are the beginning of hepatic fibrosis ${ }^{14-17)}$.

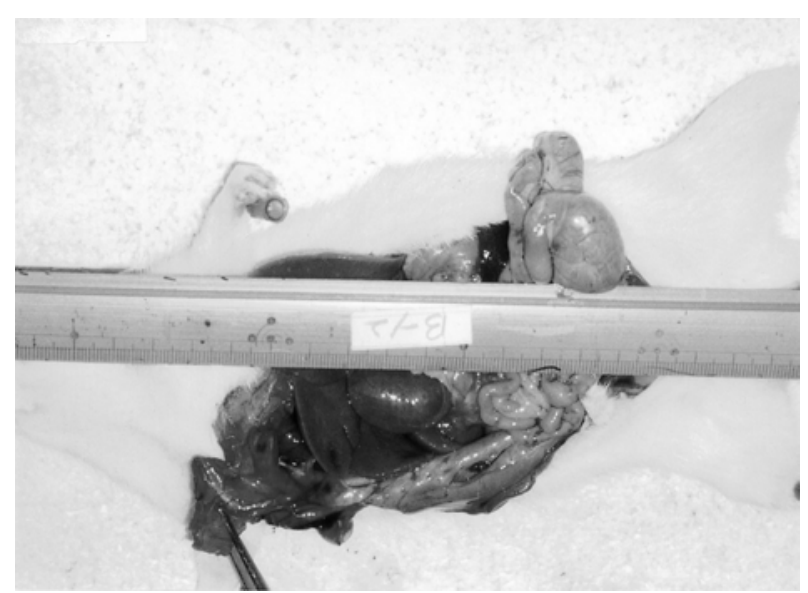

Figure 3. Ascites and significant cysts were found the fourth week after common bile duct ligation, gross findings.

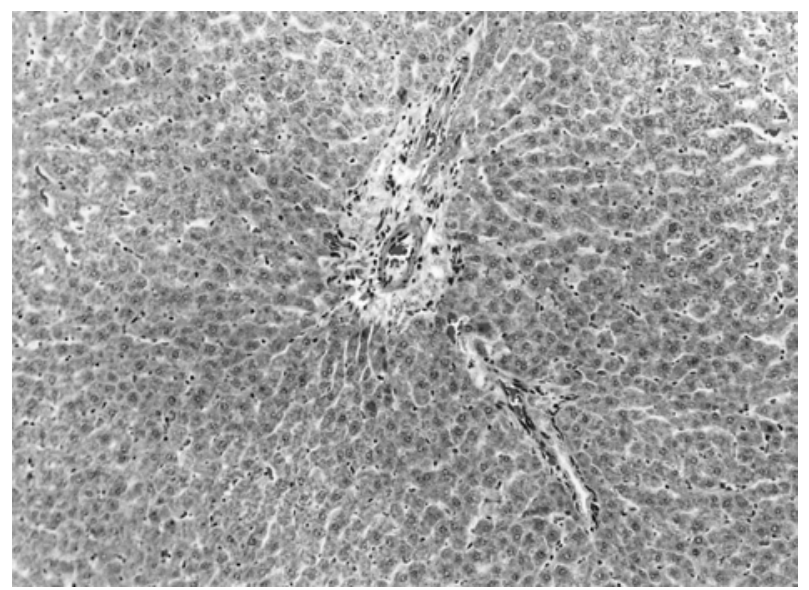

Figure 4. Portal areas contain several bile ducts and vessels (portal vein and hepatic artery branches) and are well demarcated, first week, control group, H\&E stain, $\times 100$.

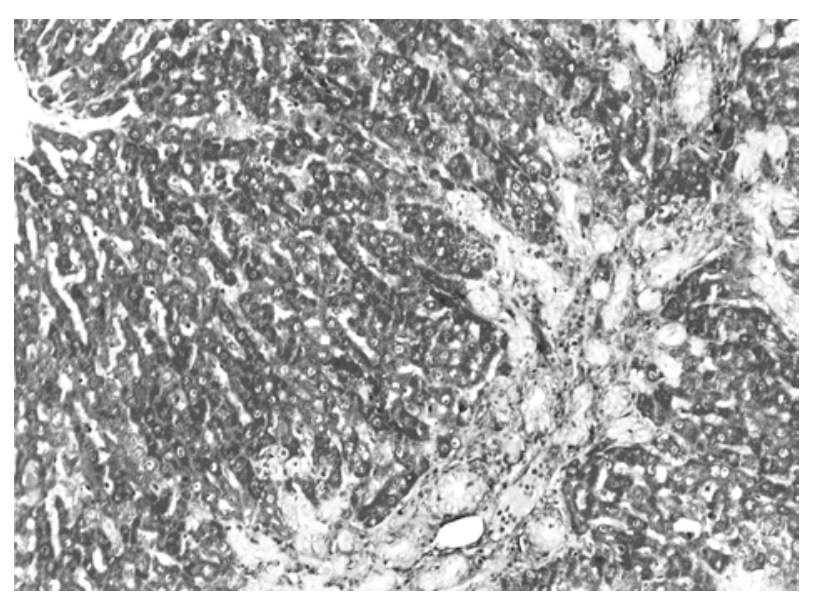

Figure 5. The increase of the bile duct proliferation was prominent compared to first week, second week after common bile duct ligation, Masson-trichrome stain, $\times 100$. 


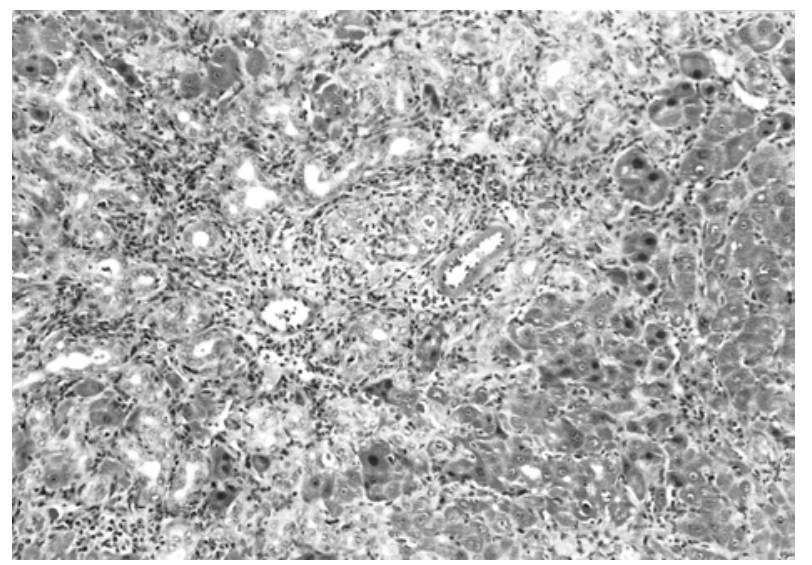

Figure 6. Distorted hepatic lobules due to increase of proliferated bile ducts, with inflammatory cell infiltration, fourth week after common bile duct ligation, H\&E stain, $\times 100$.

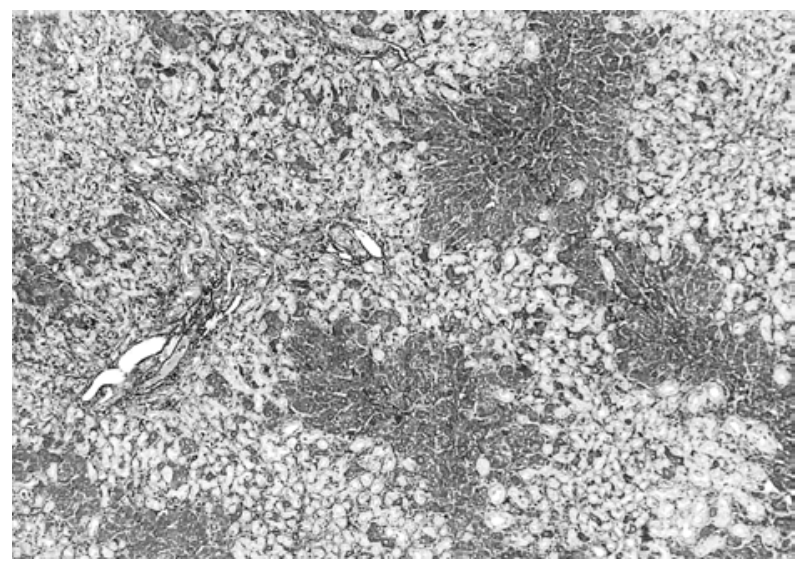

Figure 7. Portal-portal or portal-central areas are connected by proliferated bile ducts, and hepatic lobular structures are distorted, sixth week after common bile duct ligation, Masson-trichrome stain, $\times 40$.

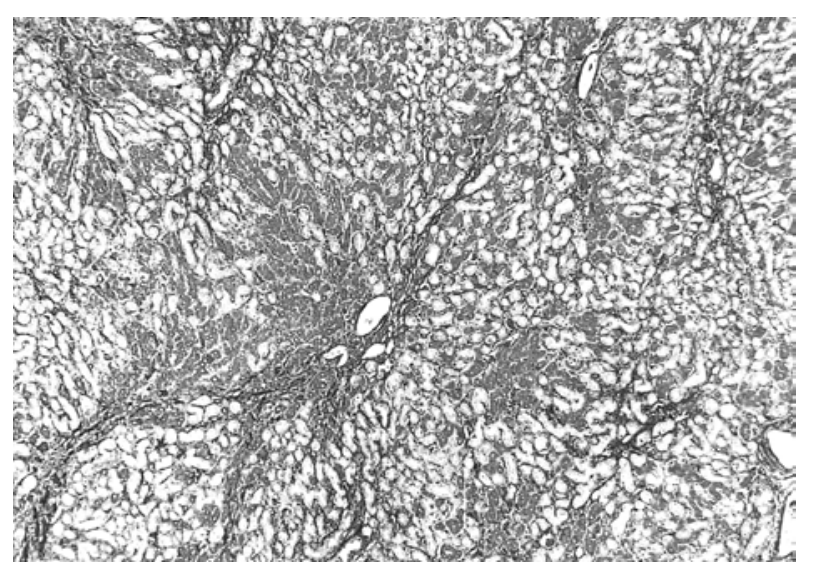

Figure 8. Most hepatic lobular areas are replaced by proliferated bile ducts and fibrous tissues (a feature of secondary biliary cirrhosis), Masson-trichrome stain, eighth week after common bile duct ligation, $\times 100$.

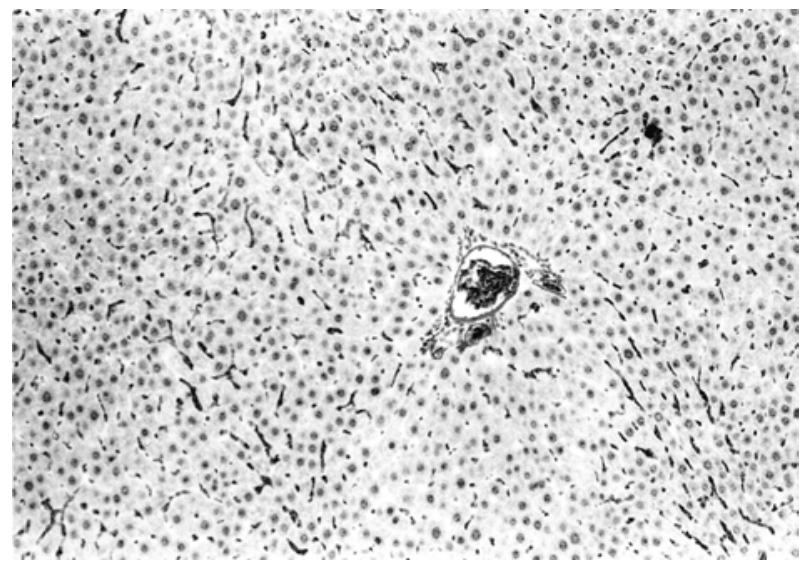

Figure 9. Normal portal areas were preserved. Hepatic artery, bile duct and portal vein were stained with alpha-smooth muscle actin. Control group, alpha-smooth muscle actin immunohistochemical stain.

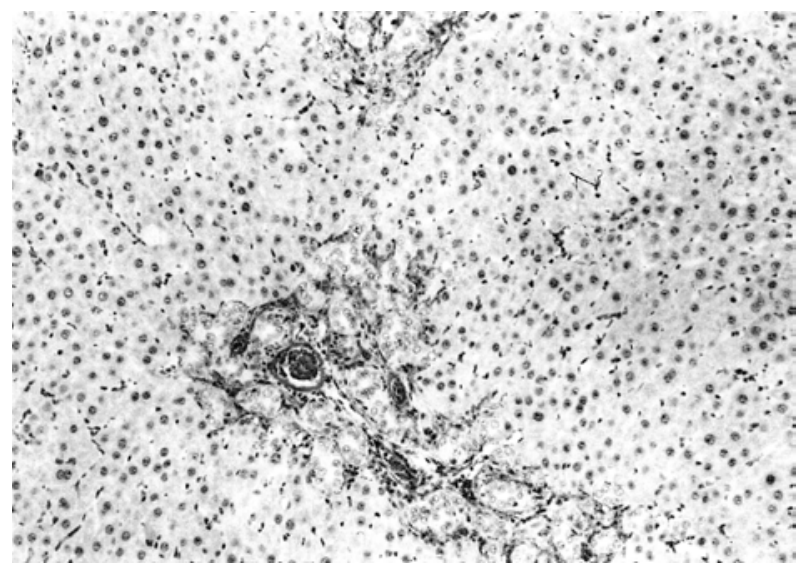

Figure 10. Focal necrotic area in the hepatic lobule was found and alpha -smooth muscle actin stain was positive in some areas, second week after common bile duct ligation, alphasmooth muscle actin immunohistochemical stain.

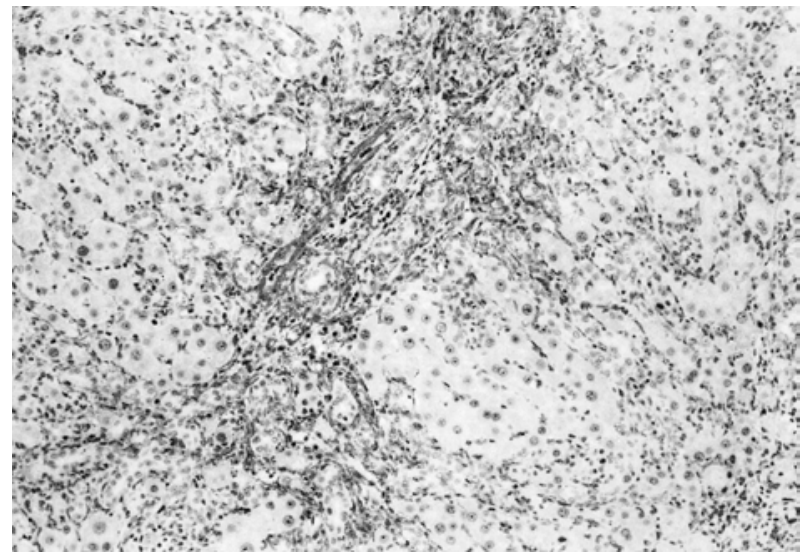

Figure 11. Normal hepatic lobular areas are replaced by proliferated bile ducts. Areas of positive stain with alpha-smooth muscle actin were prominent compared to fourth week, sixth week after common bile duct ligation, alpha-smooth muscle actin immunohistochemical stain. 


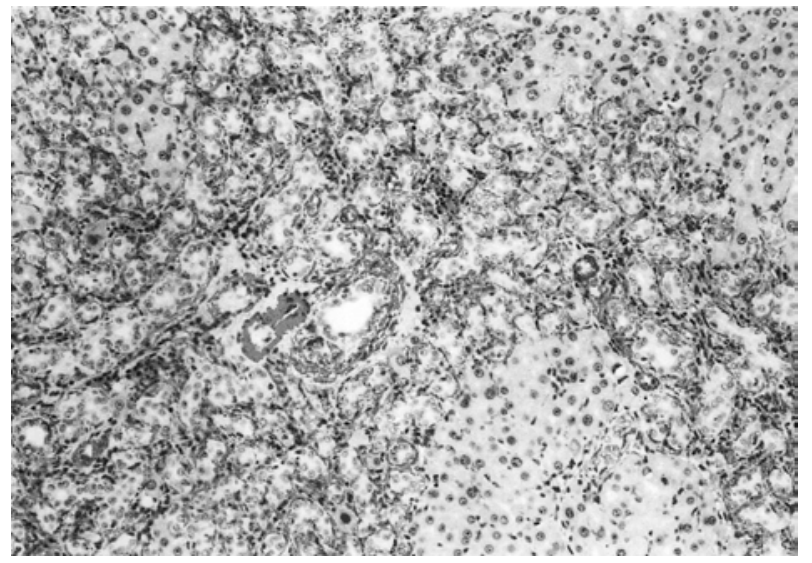

Figure 12. Most hepatic lobular areas are replaced by proliferative bile ducts and fibrous tissue. Alpha-smooth muscle actin was stained in proliferative periductular areas, eighth week after common bile duct ligation, alpha-smooth muscle actin immunohistochemical stain.

Transforming growth factor $\beta 1$ (TGF- $\beta 1$ ) is the most potent fibrogenic cytokine and plays an important role in the activation and regulation of hepatic stellate cells. It is known that TGF- $\beta 1$ is a regulatory cytokine in the growth and differentiation of cells and plays a pivotal role in the process of wound healing and fibrogenesis. TGF- $\beta 1$ is secreted from various cells including Kupffer cells, activated stellate cells and hepatocyte, and is related to the synthesis of fibronectin, type I collagen. TGF- $\beta 1$ increases in advanced fibrosis but is not expressed in normal liver tissue ${ }^{18-20)}$.

This study shows that serum TGF- $\beta 1$ level was higher in the common bile duct ligation group than in the control group. Similary, TGF- $\beta 1$ expression increases in CCL4 induced acute hepatic injury ${ }^{21)}$.

In liver biopsy findings, bile ducts proliferate after bile duct ligation, and maximal proliferation is seen at the eighth experimental week. The changes of serum cytokines were compared with microscopic findings. Alpha smooth muscle actin is present in smooth muscle cells near the biliary structure and is a stained cytoskeletal structure in the hepatic stellate cell. The degree of a-SMA stain represents the extension of fibrosis, indirectly. In our study, TGF- $\beta 1$ level was correlated with the degree of a-SMA stain.

$\mathrm{IL}-10$ is a potent anti-inflammatory cytokine that inhibits the synthesis of pro-inflammatory cytokines and it down-regulates superoxide synthesis ${ }^{22,}{ }^{23}$. IL-10 increases in the early stage of stellate cell activation ${ }^{9}$. Expression of IL-10 in inflammatory tissue is related to the improvement of inflammation. IL-10 down-regulates the expression of type 1 collagen genes and up-regulates the matrix metalloprotease-1 (interstitial collagenase) and matrix collagenase-3 (stromelysin-1 $)^{24}$. Recently, it was found that IL-10 deficient knocked-out mice have more neutrophil infiltration and severe fibrosis after various hepatic injuries $^{25-28)}$. Thus, $I L-10$ has an important role in hepatic fibrosis as an anti-fibrotic agent. A recent animal study showed that the expression of IL-10 mRNA increases in the early period in bile duct ligation rats ${ }^{29}$. In this study, serum concentration of $\mathrm{IL}-10$ is highest at the first and second experimental weeks. Thereafter, serum concentration of IL-10 decreases. We assumed that IL-10 has a pivotal role in fibrosis as an anti-fibrotic agent, and that a therapeutic use of this cytokine can be expected. In conclusion, our findings were a long-term study compared with previous extrahepatic cholestatic study in rats, and several cytokines were involved, including TGF- $\beta 1$, IL-6. Especially, IL-10 may be involved in antifibrogenesis.

\section{REFERENCES}

1) Choo KR, Kim GR, Chung YH, Lee YS, Suh DJ. Serologic profiles for hepatitis $B$ virus infection of Korean adults in the late 1990s: survey data of 77, 363 health screener. Korean J of hepatology $S 9$ (A), 1998

2) Seo KS, Lee BS, Sung JK, Lee SW, Kim SH, Kim NJ, Lee HY. The causes and complications of liver cirrhosis during the recent 5 years. Korean $J$ of hepatology 3 : 202-209, 1997

3) Statistics in cause of death 2000. Korea National Statistical Office(on-line search).

4) Brenner DA, Rippe RA, Rhodes K, Trotter JF, Breindl M. Fibrogenesis and type I collagen gene regulation. J Lab Clin Med 124: 755-760, 1994

5) Olaso E, Friedman SL. Molecular regulation of hepatic fibrogenesis. J Hepatol 29: 836-847, 1998

6) Friedman SL. Cytokines and fibrogenesis. Progress in liver diseases, Philadelphia: W.B. Saunders, 1999

7) Sporn MB, Roberts AB, Wakefield LM, Assoian RK. Transforming growth factor-beta: Biological function and chemical structure. Science 233: 532-534, 1986

8) Sporn MB, Roberts AB, Wakefield LM, De Crombrugghe B. Some recent advances in the chemistry and biology of transforming growth factor-beta. J Cell Biol 105:10391045, 1987

9) Wang SC, Tsukamoto H, Rippe RA, Schrum L, Ohata M. Expression of interleukin-10 by in vitro and in vivo activated hepatic stellate cells. J Biol Chem 273: 302-308, 1998

10) Tsukamoto H. Is interleukin-10 antifibrogenic in chronic liver injury? Hepatology 28: 1707-1709, 1998

11) Matsumara $Y$, Sakaida I, Uchida $K$, Kimura $T$, Ishihara $T$, Okita K. Prolyl 4-hydroxylase inhibitor (HOE 077) inhibits 
pig serum induced rat liver fibrosis by preventing stellate cell activation. J Hepatol. 27:185-192, 1997

12) Conn $\mathrm{HO}$, Atterbury $C E$, Schiff L, Schiff ER. Disease of the liver volume 1, 8th ed. pp. 371-385, Philadelphia: J.B. Lippincort company, 1993

13) Cotran RS, Kumar V, Robbins SL. Robbins pathologic basis of disease. 6th ed. Philadelphia : WB Saunders: 1999.

14) Pinzani M. Hepatic stellate(lto) cell: expanding roles for a liver-specific pericyte. J Hepatol 22: 700-706, 1995

15) Lee KS. Pathogenesis of hepatic fibrosis. Liver cirrhosis. 1 st ed. Seoul Gun Ja press. P. 27-42, 1995

16) Czaja MJ, Weiner FR, Flanders KC. In vitro and in vivo association of transforming growth factor-beta1 with hepatic fibrosis. J Cell Biol 108: 2477-2482, 1989

17) Mc Guire RF, Bissell DM, Boyles J, Roll FJ. Role of extracellular matrix in regulating fenestrations of sinusoidal cells isolated from normal rat liver. Hepatology 15: 989-997, 1992

18) Castilla A, Prieto J, Fausto N. Transforming growth factor $\beta 1$ and ain chronic liver disease. N Engl J Med 324: 933-940, 1991

19) Nakatsukasa H, Evarts RP, Hsia CC, Thorgeisson SS. Transforming growth factor $\beta 1$ and type I collagen transcripts during regeneration and early fibrosis of rat liver. Lab. Invest 63: 171-180, 1990

20) Border WA, Noble NA. Transforming growth factor beta in tissue fibrosis. N Engl J Med 331: 1286-1292, 1994

21) Lee Jl, Lee KS, Chung JP. The changes of transforming growth facto- $\beta 1$ expression and effect of vitamin $E$ in the acute rat liver injury with carbon tetrachloride. Korean $\mathrm{J}$ of hepatology 6: 147-155, 2000
22) Grewe M, Gausling R, Gyufko K, Hoffmann R, Decker $K$. Regulation of the mRNA expression for tumor necrosis factor-alpha in rat liver macrophages. I Hepatol 20: 811-818, 1994

23) Thompson KC, Fallowfield J, Gentry J, Sheron N. Effects of interleukin 4, interleukin 10 and interleukin 13 on production of TNF alpha by rat Kuffer cells(Abstract). Hepatology 24: 329A, 1994

24) Reitamo S, Remitz A, Tamai K, Uitto J. Interleukin-10 modulates type I collagen and matrix metalloprotease gene expression in cultured human skin fibroblasts. J Clin Invest. 94: 2489-2492, 1994

25) Kennedy MK, Torrance DS, Picha KS, Mohler KM. Analysis of cytokine mRNA expression in the central nervous system of mice experimental autoimmune encephalitis reveals that IL-10 mRNA expression correlates with recovery. J Immunol 149: 2496-2505, 1992

26) Tompson K, Julia M, Jon F, Martin M, Harry MS, Nick, S. Interleukin-10 expression and function in experimental murine liver inflammation and fibrosis. Hepatology 28: 1597-1606, 1998

27) Louis H, Jean-Luc VL, Wei W, Quertinmont E, Degraef C. Interleukin-10 controls neutrophilic infiltration, hepatocyte proliferation and liver fibrosis induced by carbon tetrachloride in mice. Hepatology $28: 1607-1615,1998$

28) Rockey DC, Maher JJ, Jarnagin WR, Gabbiani G, Friedman SL. Inhibition of rat hepatic lipocyte activation in culture by interferon-gamma. Hepatology 16: 776-784, 1992

29) Saixi CW, Mitsura O, Laura S, Richard AR, Hidekazu T. Expression of interleukin-10 by in vitro and in vivo activated hepatic stellate cells. J of biological chemistry 273: 302-308, 1998 